\title{
The Intra-Firm Context of Retail Expansion Planning
}

\begin{abstract}
The benefits that rigorous analysis can have for retail store portfolio management in guiding and informing investment decisions (store expansion; closure; extension; refascia and acquisition) is well established within the economic geography research literature. However, studies of retailers addressing location planning in practice have identified wide variation in the sophistication of techniques and resources employed as well as in terms of the credibility that such research and analysis receives from senior management within the firm. By drawing on a qualitative research project involving some 40 location planning analysts, consultants and managers at UK-based retailers, we differentiate between three approaches to store portfolio decision-making that differ in terms of resource allocation, sophistication and legitimacy. We seek to explain those differences that are embedded within the context of intra-firm relations and social communities by drawing on theories from strategic management concerning core rigidities, lock-in and legitimisation, and review the challenges that location planners face in gaining legitimacy within the organisation, along with strategies appropriate for increasing their acceptance and influence across the firm.
\end{abstract}

Keywords: intra-firm relations; location planning; core rigidities; lock-in

Steve Wood

School of Management

University of Southampton

Southampton

Hampshire

SO17 1BJ

s.m.wood@soton.ac.uk
Jonathan Reynolds

Saïd Business School

University of Oxford

Park End Street

Oxford

OX1 1HP

jonathan.reynolds@sbs.ox.ac.uk

Submitted to Environment and Planning A. $2^{\text {nd }}$ Revision April 2011

\section{Acknowledgements}

This work is supported by The Nuffield Foundation (Grant No: SGS/36175). We would also like to thank the Society for Location Analysis for their support of this project and for helping us in gaining access to numerous location planning departments of UK retailers. We appreciate the helpful feedback both from the editor and the referees on earlier drafts of the manuscript. 


\section{Introduction}

Economic geographers have a long history of studying the branch networks of service firms, in the process recognising the importance of strategic planning along with the wider implications of a network's growth and contraction over time (Marshall et al., 2000; Leyshon and Thrift, 1997; Willis, 2001). In particular, it is well known that location decision-making underpinned by rigorous spatial research and analysis is critical for retailers in both domestic and international contexts (Lowe and Wrigley, 2010; Poole et al., 2006; Wrigley, 1988). While the location planning departments of retailers provide advice for senior management in relation to a firm's overall locational strategy and the spatial consequences of any planned format development (Bennison et al., 1995), rigorous analysis at the monadic level is also undertaken - where store expansion and management are considered at the scale of the individual catchment and specific development opportunities are assessed by means of a forecast of potential sales to determine a likely return-on-investment (Hernández et al., 1998).

Academic research concerning location planning within economic geography has contributed to the development of data intensive modelling and assessment techniques to support such decision-making, with resultant improvements in forecast accuracy which are well known to retailers (Birkin et al., 2002; Mendes and Themido, 2004; Rogers, 2005; Wrigley, 1988). Indeed, over a long period, authors writing in Environment and Planning publications have contributed important insights into the development and refinement of such methodologies (Armstrong et al., 1990; Clarke et al., 2003; Kohsaka, 1993; Miller and Lerman, 1981). Meanwhile, related work has explored how site research expertise in practice can be intelligently leveraged (Lowe and Wrigley, 2010; Tacconelli and Wrigley, 2009; Wood and Tasker, 2008).

However, despite the availability of increasingly data driven and complex techniques to appraise development opportunities, and their well publicised successful adoption by a number of major retailers, a growing research literature has uncovered both the extent and nature of relatively unsophisticated locational decision-making across the industry in practice (Hernández and Bennison, 2000; Pioch and Byrom, 2004; Reynolds and Wood, 2010). Unpicking this conundrum is the focus of this paper. As ReVelle and Eiselt (2005, page 15) reflect, there is a gulf between theoretical model development and the practical usage of these tools within organisational contexts, particularly in 
'finding consensus among groups of decision-makers, and "selling" agreed-upon location choices'.

In this research paper, by drawing on a semi-structured interview and focus group methodology involving approximately 40 location planning analysts, consultants and managers across a range of retail firms, we seek to understand the difficulties experienced in securing dedicated technological and human investment to resource sophisticated analysis; the challenge of influencing the decision-making processes of senior management and the broader problem of gaining legitimacy for analysts' roles within the firm. In doing so, we consider the relational, networked nature of intra-firm decision-making in this respect. We supplement the economic geography research literature by drawing upon the field of strategic management to understand the potential effects of core rigidities and corporate lock-in that affect a firm's necessary investment in, development of, and receptiveness to, the location planning function. More specifically, the objectives of this research paper are: (1) To understand the difference in the acceptance of location planning expertise across a range of retailers operating in the UK; (2) To identify the core rigidities and lock-in that may prevent retailers from fully benefitting from sophisticated location planning analysis; (3) To suggest approaches that location planners might employ to increase their intra-firm legitimacy.

This paper is organised as follows: first, we review the current academic literature concerning store network analysis, how this relates to organisational context, relational networks and intra-firm relations as well as the potential implications for the practice of location planning within retailing. In doing so we draw on extant strategic management research to examine how firms can become 'locked in' to established routines and practices. Second, we briefly discuss the methodology adopted in the research before, third, analysing our results to identify three approaches to location analysis and decision-making within retail firms that vary markedly in the sophistication, level of investment and the subsequent credibility that they foster within the organisation. Finally, we examine the implications of our findings for location planning departments wishing to more effectively embed their role and function within the retail firm's network of relations. 


\section{Location planning in retailing: modelling potential and organisational context}

In an article that widely influenced the social sciences, March (1991) examined the need for all firms to actively manage the potentially conflicting goals of both exploiting and exploring their environment. Other commentators have contextualised this in terms of reconciling the 'alignment' of activities to short-term competitive surroundings with an 'adaptability' to facilitate the change and growth necessary for the challenges that accompany longer term time horizons (Raisch and Birkinshaw, 2008). In doing so, firms must be 'ambidextrous' in their operation: 'aligned and efficient in their management of today's business demands, while also adaptive enough to changes in the environment' (Gibson and Birkinshaw, 2004, page 209). Within retailing, this principle sees firms acting to maintain the efficiency and performance of their existing stores, product offer, supply chains and brands ('exploitation' in March's terms), while also experimenting and developing capacity for the future ('exploration') - and where the expansion and continual management of the store portfolio is of particular concern (Wood et al., 2010). A location planning department within a retailer therefore has to accommodate both of the learning objectives identified by March (1991): reconciling the management and continued upgrading of the existing store portfolio (exploitative) along with the formation of an ideal spatial and format-related strategy alongside the directed search for (and evaluation of) future growth opportunities (explorative).

\section{Location planning model development and organisational context}

The improved capability of increasingly sophisticated assessment techniques employed within store portfolio decision-making has been a particular feature of the retail geography and retail management literature (see Table 1 for a summary). This focus has been demonstrated most clearly in the forecasting of new sites, in relation to extensions, replacements and acquisitions, as well as for the refurbishment of existing units (Bennison et al. 1995; Birkin et al., 2002; Hernández et al., 1998). However, in recent years there has been a more intensive research focus on the employment of these methods within the context of practicing retailers. While the application of such techniques has partly been driven by increased investment risk and the sunk costs of store development due to the limited availability of viable land for store development, especially within the context of tightened land use planning regulations (Wood et al., 2010; see Clark and Wrigley, 1995), there remain substantial variations in practice.

Table 1 about here 
There is increasing awareness within the geographical modelling research literature of the gulf between theory and practice in retail location analysis. As Birkin and colleagues (2010, page 423) recently suggested:

'Models built for private- sector clients must reflect real consumer behavior and accurately predict the initial unknowns, such as the turnover of individual stores. If they do not, then a retailer will walk away and have nothing to do with them!'

Unsurprisingly, studies of retail location analysis in practice suggest that quantitative analytical techniques may be employed only to a limited extent while the execution of modelling and its links with decision-making are not as mechanistic as might be assumed from some of the theoretical research literature. Small and independent operators have been identified as employing "subjective, intuitive "rules of thumb" (Pioch and Byrom, 2004, page 230), while surveys of location planning departments suggest decision-making relies on a blend of art and science (Hernández and Bennison, 2000; Reynolds and Wood, 2010). Experienced analysts are known to draw on observation and intuition in the absence or partiality of valid data or appropriate techniques (Clarke et al., 2003; Wood and Browne, 2007; Wood and Tasker, 2008). Furthermore, differences in executives' understanding concerning the drivers of store performance - between location planning analysts and senior management for example - may lead to decisions that fail to be underpinned by analytics (Clarke and Mackaness, 2001). Indeed, a recent article in this journal has speculated for example that, irrespective of data analysis, male executives are naturally more bullish about store expansion when compared to female managers (Pal et al., 2010).

The culture of the individual retailer has also been identified as an important consideration in determining location strategy. Theodoridis and Bennison (2009) distinguish between those retailers that exhibit 'complexity adapting' characteristics (which accept the business environment as unstable and therefore adapt their routines, assessment methods, strategies and techniques accordingly) and 'complexity absorbing' organisations (which tend to retain a long-term strategy and resist change).

Importantly, those retailers that have invested in, and subsequently developed, location planning expertise are known to obtain considerable benefits from accurately appraising and forecasting the value of potential opportunities (Rogers, 2005). A well-known 
example is UK food retailer Tesco which, having developed its UK location planning expertise over a number of decades (Penny and Broom, 1988), leveraged this capability in its overseas expansion. Such insight has provided the business with accurate and timely strategic advice concerning appropriate formats and customer related propositions (Coe and Lee, 2006; Lowe and Wrigley, 2010; Tacconelli and Wrigley, 2009). An informed strategic planning function is especially important given the role of governments in modifying and enforcing regulatory regimes which can have wideranging implications for store network management (Poole et al., 2006). Clearly then, while investment in analysts, models and data-sets may offer a significant benefits, the practical adoption of location planning within retail organisations is by no means straightforward.

\section{Bounded rationality, relational networks, core rigidities and lock-in}

The research generated within the fields of economic geography and strategic management provides context to aid our understanding of the divergent approaches to developing location planning expertise that in turn inform store portfolio decisionmaking. Here, we draw on a relational understanding of the firm, theories of corporate lock-in, core rigidity and the situated nature of decision-making, along with the implications that these issues have for legitimising new practices.

\section{Relational networks and power within the retail firm}

An important component in understanding the intra-firm context of strategic planning is the conceptualisation of the retailer in what economic geographers have called a relational and networked approach. This sees economic actions being viewed as a context-specific process, embedded within structures of social (and economic) relations - on the one hand within the firm itself where one needs to closely conceptualise social and power relations (intra-firm relations) (Yeung, 2005a,b), but also beyond the firm to encompass relationships with suppliers, customers and wider institutions (involving inter-and extra- firm relations) (Bathelt and Glückler, 2003; Dicken and Thrift, 1992; Wrigley et al., 2005).

The relational approach has made a considerable contribution to our understanding of the geography of services (Hess and Yeung, 2006). In particular, the global production network (GPN) perspective delivers 'a better analytic purchase on the changing international distribution of production and consumption' (Henderson et al., 2002, page 
438). This analytical lens has further developed the conceptualisation of economic activity as a 'chain' building towards an 'essentially networked' understanding that includes the inter-related activities of a wide range of actors that may include whole firms (or parts of them), the state and consumers (Dicken and Malmberg, 2001, page 347). Such interactions are seen as cutting across national economies and boundaries but also the traditional boundaries of the firm (see Coe et al., 2008 for a recent summary).

Within retailing, the GPN approach has particularly contributed to our understanding of retail TNC development. Especially important has been the development of Hess' (2004) work that distinguished between territorial, network and societal embeddedness and led to subsequent research examining how retailers are influenced by the structures within their home and the host market (Wrigley et al., 2005). In the process, research has emerged that has examined the attempts of retail TNC's to "ground" or territorially embed their store and supply chain networks within new host markets - whether this is through 'strategic localization' following extensive market analysis (often led by location planners) and/or through learning from partners or wider stakeholders (Coe and Hess, 2005; Coe and Lee, 2006; Lowe and Wrigley, 2010). However, retail TNCs contribute to influencing institutional change within their host environment whilst simultaneously adapting to it (Durand and Wrigley 2009). Consequently, 'second mover' responses from indigenous retailers and the government (the latter, for example, via changes to regulatory frameworks) are likely and require continued refining of operations (Coe and Wrigley, 2007).

Meanwhile, relational economic geography conceptualises the firm itself as a set of social communities 'involving multiple social actors that through their interactions, conflicts, negotiations and compromises determine the way a firm is governed and structured' (Faulconbridge, 2010, page 274). Such interaction is important in terms of managing (and formulating new) knowledge within the firm. Frequently economic geographers have conceptualised the knowledge management process through the concept of 'communities of practice' (Lave and Wenger, 1991) which refers to groups within a single organisation (or through pre-established alliances) who are engaged in the same practice and communicate about their activities to solve practical problems (Moodysson 2008, page 453; Amin and Cohendet, 2004). Using this networked approach, economic geographers have examined the organisational geographies of a 
range of firms, including many service businesses, such as architecture (Faulconbridge, 2010b); advertising (Faulconbridge, 2006); retail TNCs (Currah and Wrigley, 2004) and law firms (Faulconbridge, 2007) amongst others.

Mediating the relational geographies of the firm are differing degrees of power and authority between actors. As Yeung (2005b, page 309) puts it:

'[The firm] is a contested site for material and discursive constructions at different organisational and spatial scales. The firm is necessarily a site of power relations and power struggle among actors; it is a socio-spatial construction embedded in broader discourses and practices'.

Drawing on the work of Allen (2003), Faulconbridge and Hall (2009) note how power can be conceived as structural; a 'thing' that is 'possessed' by individuals. Even if actors do not use their influence, they are still widely regarded as powerful. In contrast, Allen's work also notes how power can also be relational and emerges in (and through) social interaction. As such it is not regarded as a 'thing' but is instead something embedded in (and dependent upon) social and economic actions and contexts. Weller (2009) argues that an actor's 'place' within a network is therefore critical to the realisation and appropriation of power. In turn, physical, cultural, virtual and organisational proximity within networks partly governs such power relations (Jones and Search, 2009). Power may therefore be a facilitator of action, but also a constraint, depending on one's position within a relational network:

'[Power may provide] relative room to move, a degree of freedom that facilitates certain types of action taken at particular moments in time, while powerlessness becomes an absence of manoeuvrability, the sense of being 'cornered' in space and time' (Weller, 2009, page 792).

\section{Lock-in, rigidity and situatedness within intra-firm relations}

Both the economic geography and strategic management literatures have long recognised the role of what Simon (1957) refers to as the 'bounded rationality' of economic agents and the wider role of cognition and context (Clark, 2010). This partial knowledge means that managers often a rely on heuristics (mental shortcuts) rather than extensive analysis as 'intuition and imitation play an important role in how people make choices, and that preferences (including risk tolerance) are not stable but are affected by context and framing' (Strauss, 2008, page 141). As Daft and Weick (1984) recognised over a quarter of a century ago, the competitive environment is interpreted through the 
lens of 'the firm', along with management's core organisational beliefs and embedded world view. This will have developed both within the firm, but is also informed by the previous experience of management across other businesses. This 'interpretive scheme' of the organisation serves to filter 'the perceptions of knowledge requirements, the value of available information and know-how, and the value of knowledge investments' (Reus et al., 2009, page 390). At the heart of the decision-making process are social context and the bureaucratically created routines and processes that permit some things and inadvertently act to prevent others (Lam, 2000). Essentially then, knowledge within the firm is framed within intra-firm debates but is also affected by, and itself influences, inter- and extra-firm relations and the constituent power relations therein (Strauss, 2009).

An important issue explored within the strategic management literature, and to some extent within economic geography, is why firms continue to pursue a particular strategy even in the light of clear evidence that indicates the necessity of change. While the concept of lock-in has a history stretching back over twenty years (Arthur, 1989), within economic geography this concept has been employed in the conceptualisation and explanation of the persisting geography of industrial spaces (Hassink, 2007; SornnFriese and Simoni Sorensen, 2005). As Grabher (1993, page 256) suggests, the specialised competencies that underpin the growth of industrial districts can ultimately turn 'into stubborn obstacles to innovation', in the form of: functional lock-in where there are overly rigid inter-firm networks - in essence the negative implications of embeddedness within a region (Uzzi, 1997); cognitive lock-in where actors inflexibly focus on a dominant path and common viewpoint; or political lock-in where overly strong relationships between private and public actors prevent appropriate and required adaptation. Meanwhile, the strategic management literature has utilised the concept of lock-in to understand strategy at the level of the firm.

In a series of publications that were influential across the social sciences, Schoenberger argued that firms can become 'locked-in' to a strategy such that adaptation and the adjustment of routines become difficult. This is often associated with social embeddedness and with individuals' own interpretative schema that 'although quite successful in the circumstances which produced them, may lead to serious misjudgments when the circumstances change sufficiently' (Schoenberger, 1994, page 441). At its worst, management can become so accustomed to success that critical 
analysis and receptiveness to internal strategic advice deteriorates. This issue is perpetuated with the tendency for senior managers to 'unwittingly collude among themselves to avoid tests' as this may threaten their own authoritarian position and status (Weick, 1979, page 151).

In addition, lock-in can derive from inflexible corporate routines and ways of working that ossify and restrict adjustment. In this manner, 'an organizational form that was once itself an impressive innovation becomes the chief obstacle to further innovation' (Schoenberger, 1997, page 84). Such rigidity can lead to product, country and functional silos within firms that contribute to the misallocation of resources, inconsistency in the messages provided to the market and a failure to leverage scale economies (Aaker, 2008).

The principle of lock-in is closely related to that of 'core rigidities', which refers to the skills and systems that served the firm well in the past (and may remain appropriate for some projects) but which may also represent inappropriate sets of deeply embedded knowledge that create significant problems (Leonard-Barton, 1992, page 118). Gilbert (2005) distinguishes between two types of rigidity that restrict the necessary adaptation demanded by changes in competitive conditions: namely resource rigidity and routine rigidity. The former relates to a failure to change investment patterns. Routine rigidity requires further explanation. Gilbert (2005, page 742), drawing on the work of Nelson and Winter (1982), contends that routines are 'repeated patterns of response involving interdependent activities that become reinforced through structural embeddedness and repeated use'. He argues that routines can become so entrenched and self-reinforcing that they are difficult to adjust when change is required.

The prevalence of routine and resource rigidity can make the firm blind to changes in its environment, which may not be harmful in stable markets but makes the firm essentially reactive in orientation (Tollin and Jones, 2009). This may result in an inability to question and interrogate the small failures which can be precursors to more significant problems. In summary, the inertia that is characteristic of lock-in and rigidity stems 'from sunk costs in past investments and entrenched social structures, and also to organizational members becoming attached to cognitive styles, behavioural dispositions, and decision heuristics' (Volberda, 2006, page 954). 


\section{Senior and middle management hierarchies in decision-making}

With strategic planning increasingly recognised as a context-dependent and embedded socially-accomplished activity, the relationship between a firm's main board and its middle management is crucial to success. Within our study this is especially important in securing and maintaining investment for a location planning function which must build credibility and gain 'the ear' of senior management, members of which are ultimately responsible for the decision-making that takes place.

Jarzabkowski (2005) differentiates between different levels of interaction between main boards and middle management in the strategising process. On the one hand, procedural strategizing focuses on formal administrative practices such as committees through which strategy is documented and formally embedded within the organisation. Meanwhile, interactive strategizing is more open in terms of innovative thinking, amending processes, and 'involves direct, purposive, face-to-face interactions between top managers and other actors' and allows 'top management to reinforce their own interpretations of activities as well as to negotiate these interpretations with others' (Jarzabkowski, 2005, page 51).

The practice of interactive strategizing typically involves critically informed and open discussion between the Board and lower ranks of the organisation, and comprises 'open and direct communication, persuasion and negotiation in continuously building shared frameworks of meaning about strategy' (Hendry et al., 2010, page 40). Similarly Hoon (2007, page 944) underlines the importance of 'informally scheduled interactions, embedded within formal committee-based relationships between senior and middle managers' in shaping strategy and potentially avoiding pitfalls associated with lock-in, rigidity and inertia.

Gaining such linkages within the decision-making function partly rests on realising structural and interpretive legitimacy within the organisation (Hendry et al., 2010). This is affected by features of the company's internal environment such as its prior performance, history and culture as well as by aspects of its external environment including industrial and institutional norms or expectations (Hendry et al. 2010). In this context, gaining legitimacy is a gradual process made up of a number of 'small wins' to solicit new ways of working and acceptance. Reay et al. (2006) argue that it is important to fit any new developments within the prevailing systems of the firm to minimise 
disruption and opposition, while also maintaining and persistently underlining the value of those innovations. This is all the more difficult when there are likely to be competing 'institutional logics' and self-interest of other actors within the firm competing for legitimacy themselves (Reay and Hinings, 2009). In part, this means that actors may have to pursue 'rhetorical strategies' to influence management and gain legitimacy (Goodrick and Reay, 2010) - something all the more challenging where an individual's role lacks an established professional identity which can lead to engagement in discourses of professionalization to gain legitimacy (Beaverstock et al., 2010).

\section{Methodology}

This research is based on a three stage data collection process. First, we conducted an online survey relating to the assessment techniques used by individual location planning/property managers. While this is not the focus of the analysis in this paper and is reported elsewhere (Reynolds and Wood, 2010), it served to contextualise many of the issues relating to assessment sophistication and intra-firm legitimacy and aided us in devising an interview protocol. Second, our main data collection employed semistructured interviews with approximately 30 analysts and managers responsible for location planning across a range of retailers and related consultancies. Our interview sample was mainly drawn from the survey respondents but also from the membership list of a relevant industry support body: the Society for Location Analysis. Over a two year period, the authors participated in meetings within this organisation and, in doing so, became part of an extra-firm network dedicated to store development-related analysis. This provided access to a wide range of relevant actors and also led to a proliferation of interviews.

The selection of retailers provided a sample of operators across different retail sectors and firm sizes. The retailers consulted had a UK presence and were commonly based within London or another of the UK's main cities. While most medium-large sized retailers operated a location planning team of some form, sometimes these were not organized as wholly independent analysis functions, but were instead situated within a broader Property or Marketing Department. Consequently, some of our interview subjects had job titles relating to property or marketing management. In each case, we sought to speak to the most senior member of the functional team. This was often beneficial in providing access to the wider context of store development decisionmaking within the firm. The majority of analysts and managers featured also had some 
level of international network planning experience. However, this paper focuses specifically on the intra-firm context of location planning within the UK market.

Our interview sample also deliberately included a small number of location planners based in consulting firms. Such actors tend to be employed by retailers on shortmedium term contracts to provide specialist location planning expertise that was not available in-house. They tended to have extensive experience of a range of retail contexts and also, critically for this project, provided a deeper understanding of the network planning process at smaller retail firms, without a developed in-house function, which might otherwise have been overlooked in our study.

All respondents were assured of complete confidentiality at both a personal and corporate level. The interview protocol was semi-structured and loosely based around a number of themes related to portfolio development and management. Interviews were held at the head offices of the retailers and location planning consultancies and lasted for between 45 and 90 minutes. To ensure the comparability amongst interviews, the structure remained consistent: focusing on specific aspects of location planning. The discussion was then widened to consider the interviewee's additional responsibilities and influence. Typically interviews were audio recorded, transcribed and then coded and analysed in line with broadly accepted qualitative research practice (Bryman and Bell, 2003).

Having established some provisional conclusions, the third and final stage of our data collection comprised a focus group with a further 10 location planning analysts in April 2010. None of these participants had featured in the previous stage of the research. The focus group formed part of a residential executive education course focused on location planning. This session was held to determine whether provisional conclusions derived from our interviews fairly represented the nature and complexity of the issues involved. This offered an important opportunity for validation as we were able to actively probe individuals' understanding which prompted group discussion, exchanges of perspectives and deeper reflection. In order to ensure an informal atmosphere and to provide assurances of confidentiality, the sessions were not recorded, although extensive notes were taken. 
In summary, our research approach sought to reproduce the qualitative rigour commonly referred to as 'close dialogue' with important corporate actors (Clark, 1998) - a process which allows the interrogation and tracing of perceived relations between actors and their consequences within a firm's network. The need for triangulation of data within economic geographies is well-known (Yeung, 2003) - not least when interacting with industry specialists as academics are 'vulnerable to [their]... concealment and obfuscation' (Clark, 1998, page 80). We have therefore ensured that all three data collection methods were utilised to triangulate individual analyst perspectives and to inform our findings, along with wider sources of knowledge captured from our own previous professional experience in site forecasting, insights from the retail press, and active involvement with members of a location analysis industry support group.

When presenting our analysis, we have given a voice to respondents though the use of direct quotation although, by agreement, their own identity and that of their employer remain anonymous - such is the commercially sensitive nature of much of the information discussed. However, we have noted the retail sector within which the respondent is employed.

\section{A typology of location planning approaches and developing intra-firm legitimacy}

By analysing our data we have constructed a simplified typology of approaches to location planning across the sector. In doing so, we seek to explore the various degrees of sophistication employed and the resource that retailers dedicate to network planning and store/site assessment. We also contrast location planning departments' strategies to attain legitimacy and influence with senior management and identify core rigidities that may prevent decision-making from being informed by analysis rather than emotion and the personal perspectives of senior management.

Table 2 about here

\section{'Administrative' location planning departments}

The least technically developed, legitimised and resourced departments are what we refer to as administrative location planning functions (see Table 2). Here, the location planning advisory role was often given to an overburdened individual, commonly within a department that sometimes had a vested interest in particular outcomes. These 
analysts had major demands placed upon their time and often lacked the technical as well as human resources to provide the independent and analytical function to which they aspired. Occasionally they felt pressured to reach particular conclusions and expressed frustration that their analysis did not receive the consideration within the organisation that it deserved. Indeed, both the resource and routine rigidities outlined in Table 3 were particularly applicable to this category.

Table 3 about here

Within such a department, a lack of legitimacy underpinned a peripheral contribution to decision-making. Often, it could commonly provide only basic portfolio data management with minimal accountability or responsibility for informing the firm's store strategy. As one location planner at a non-food retailer reflected, the perception of her role within the Property Department led to dismay that she was not able to control the outputs and processes that remained the preserve of Property Executives:

"We do have a gravity model, which...[sits] within Property...so I don't actually have that... So I know the concept, I know how it works, but in terms of the final sales figure forecast, it's generated from them. I mean, they sit next to me, but..." (Location Planning Analyst, Non-Food Retailer).

'Administrative' location planning functions were often subsumed within the wider roles and responsibilities of Property or Marketing Departments. As one location planning consultant noted, when dealing with these organisations, there was often a lack of clarity regarding which part of the business assumed accountability for such strategic planning and decision-making:

"[Location planning] may even not be a recognised requirement and it requires selling to a number of stakeholders to get the retailer to recognise the benefits of good location planning work" (Director, Location Planning Consultancy).

As Table 3 suggests, routine and resource difficulties can restrict the development of an independent location planning function. While some analysts bemoaned a lack of transparency regarding the material benefit that accurate store assessment could provide the firm, it was felt that part of the neglect by senior management was attributable to a recurring perception of network analysis as a 'backwater', disconnected from core retail functions: 
"Location Planning...can be seen as a sort of back-room, boffin type thing that doesn't really understand the real world of retail and isn't out there on the coalface, so it can have pejorative associations" (Director, Location Planning Consultancy).

Here, we can see a lack of 'cultural proximity' to senior managers and their decisionmaking, as analysts' secondary position within the relational network of the firm leaves them with minimal power to influence strategic planning (cf. Jones and Search, 2009). Changing these perceptions is part of the solution to establishing a well regarded and legitimised location planning function within retail organisations.

\section{'Responsive' location planning departments}

Table 2 identifies responsive location planning departments as those that have some degree of autonomy and independence but are likely to be struggling to achieve the receptiveness and trust of senior management. At times this was due to engrained and rigid routines underlain by negative perceptions by senior managers over the potential for location planning to enhance their decision-making. For example, one food retail location planning manager noted how his ability to present and discuss store development opportunities at Board level had recently been removed:

"[Senior Management] said, "Look, the meeting's too big - we don't want you there anymore", which I think is a... huge mistake, because we're then relying on Property to say "actually this isn't a very good site - we don't want to do it". We'll have to rely on the fact that our network view comes across very clearly in the Board paper" (Site Research Manager, Food Retailer).

Losing the 'physical proximity' that came with attendance at Board meetings resulted in a loss of influence with decision-makers (cf. Jones and Search, 2009). Whilst departments in this category still perform site forecasting functions, the link between the data that they provided and its actual influence upon decision-making processes is unclear - indicative of a lack of organisational and cultural proximity to the upper hierarchies of the firm:

"We currently have a fairly basic role, and that is to do the site assessments... the sales forecasts, and then we issue a report when it goes to the Board. However, we don't necessarily see what happens to the reports or the numbers after we've written it and sent them off' (Location Planning Manager, Food Retailer). 
Furthermore, resource rigidity was widely acknowledged to restrict departments in this category from expanding their services as widely across the business as they might have desired (see Table 3).

Departments exhibiting these characteristics were of varying size, suggesting that any lack of legitimacy derives not so much from the expense of the resource, but more from the engrained interpretive frameworks of management in relation to the perceived value of network planning expertise. Clearly, a major concern in store development decisionmaking is that it is based on data and analysis rather than conjecture. However, in contrast to the long-term time horizons that characterise retail store estate investment decisions, it was found that all too often boardroom perspectives became clouded by short-term issues in instances when there was no location planning input in the room:

"quite a lot of the decision-making ...will depend on things like how well the business has traded in the last two weeks and how people are feeling generally, despite the fact these are long-term investment decisions" (Commercial Information Manager, Non-Food Retailer).

With the common absence of a location planning presence at the senior management decision-making meeting, there was the possibility that their report could also become diluted by other stakeholders, with other motives. As one major retailer noted:

"Property have got the responsibility for the overall paper, and they will take chunks of our paper... [They] sometimes aren't that stringent about coming back to us and checking that we're happy with what they've written" (Business Analyst, Non-Food Retailer).

Location planning managers with this qualified level of legitimacy and expertise were often acutely aware of the politically fragile nature of their position within the decisionmaking relational network of the firm. As Weller (2009, page 792) has noted, actors poorly positioned within relational networks often resort to tactical interventions. And so, at times, some location planning teams deliberately provided slightly pessimistic sales forecasts, in an attempt to counteract overly optimistic assessments of potential store performance from other stakeholders (e.g. Property Departments). This had the effect of protecting their position within the firm but also ensured that the business would be less likely to enter into a store development deal with an overly ambitious valuation: 
"We deliberately err on the cautious side on our forecasting, partly because... historically, the business has erred on the bullish side" (Commercial Information Manager, Non-Food Retailer).

\section{'Proactive' location planning departments}

Location planning functions that we classify as proactive were few in number and tended to be situated within large retailers operating in mature retail sectors where the sunk costs (and associated risks) of network development were high - such as in food retailing. They were also often businesses that maintained some form of international retail presence. In one sense therefore it is less surprising that such firms have been inclined to take well-informed and data-driven analytics more seriously. Managers from these departments typically enjoyed good access and close proximity to their senior counterparts, often at a level characterised as 'interactive strategizing' by Jarzabkowski (2005), with an accepted presence at board meetings and a well-earned reputation for independent and accurate analysis.

Proactive location planning departments tended not only to provide senior managers with forecasts concerning possible developments in the store portfolio, but were also embedded within a wider intra-firm network of influential executives situated within adjacent departments. This led to them becoming important sources of catchment and customer related data and analysis to departments across the business - including Marketing, Operations and Finance. Such location planning departments therefore possessed strong degrees of organisational, cultural and often physical proximity with stakeholders across the firm. As one location planning consultant with experience across a range of retailers noted, acceptance of the function's contribution breeds increased influence but also greater cross-working and data sharing:

“...very quickly, different Departments start to think about the implications that that [a location-based] understanding has on their business practice [and]... start to answer questions that they have and that can help about range planning, local merchandising, local marketing" (Director, Location Planning Consultancy).

Achieving legitimacy with stakeholders, and particularly senior management, takes time and partly relies on establishing the analysis function as a voice independent of any other interest group. While gaining a reputation for accuracy in forecasting is important, an even stronger source of legitimacy can come from being regarded as a supplier of wider strategic advice concerning portfolio management, customer/competitor spatial 
behaviour, and innovation. As one location planner reflected on the successful transition:

"[Previously] we were just there to supply to numbers. But I think, through a lot of hard work and getting people in Property on board, that's really changed now... I've not yet had a site going to Board that I've said to reject and they've disagreed" (Site Research Manager, Food Retailer).

Many of the location planning managers in this category therefore took a lead in setting the network planning strategy for a region which was then passed to Property Departments to be realised. Often this led to the location planning teams being assigned more strategic tasks, such as international network planning with a focus on the analysis of potential market entry and subsequent expansion planning. They were also often actively involved in strategic planning relating to actual or potential regulatory rulings. For example, this saw some departments working with Property teams to devise workable modifications to store development schemes on constrained town centre sites in the context of UK land-use planning law (see Wood et al., 2010). Such developments included stores with sales floors on two levels or being set on stilts with car parking located below. Other examples of sophisticated analysis by proactive departments saw some undertaking scenario planning with respect to potential consequences of recent Competition Commission inquiries (cf. Hughes et al., 2009; Wrigley et al., 2009). Such analysis provided senior managers with important information concerning the impact of likely outcomes and the viability of responsive strategies both at a macro (portfoliowide) and micro (individual catchment) scale.

\section{Towards a networked and inclusive strategic planning function}

Our interviews also indicated that a range of strategies are employed by location planning functions to erode entrenched routine and resource rigidities and to challenge the engrained interpretative schemas held by both middle and senior managers. These are difficult to achieve, which partly explain the persistence of administrative and responsive functions across the sector.

Proactive location planning departments made concerted efforts to influence the nature of intra-firm relations to maintain and develop their legitimacy. At the heart of this process is accessing the centralised power of senior management, who 'drive networks and make things happen' (Yeung, 2005b, page 316). Proactive departments therefore 
directed significant energy at gaining the trust and tacit approval of particular stakeholders throughout the appraisal process to avoid "grandstanding" within formalised Board meetings:

"...we have meetings with representatives of the Board, to start with... It goes to effectively a pre-meeting beforehand anyway, where we will be looking at the proposed catchment and we will be explaining what we're doing and why we're looking at a certain store.... So we've effectively got a buy-in beforehand" (Location Planning Manager, Electrical Retailer).

As an important part of gaining legitimacy with stakeholders and fostering an increased understanding of their role, successful location planning departments made concerted efforts to reposition themselves within inter-departmental networks. One department store retailer acknowledged how the relationship with the Property Department was strengthened by conducting joint site visits, for example. As the site progressed and warranted deeper analysis and consideration, these visits would also include senior management:

“...we'd take Property with us, so every opportunity we were looking at, we'd go out together... We're likely to go back two or three times, especially if it was progressing, and you'd go back with various people, right up until you'd take the Board to a site" (Analyst, Department Store Retailer).

Such initiatives increased cultural and physical proximity with important decisionmakers, leading to further inclusion and legitimisation of the location planning function.

In the process of building a network of supporters of the location planning function, proactive departments became easily accessible providers of data and analysis relating to catchments and customers. In doing so, they raised the profile of the team and increased relational proximity to important stakeholders beyond senior management. One manager of a location planning department that currently exhibits characteristics typical of such a function suggested, this cultural change was difficult but essential to achieve:

"historically, they kept themselves in a little bit of a silo, and I've pushed them out of that silo, so they're speaking to the Area Managers from day one, and the Regional Managers will come over and talk to us about a site" (Store Forecasting Manager, General Merchandiser). 
Constructing such networks was not only concerned with maintaining legitimacy per se, but was also a way of accessing a vital flow of information concerning store catchments, competitor openings, potential sites and allowed managers to keep abreast of company politics.

\section{Managing communications strategically}

Raising the profile of the location planning department with internal stakeholders was partly dependent on ensuring that strategic advice was presented in a form that senior management could easily digest. This required a departure from a purely academic perspective on modelling in favour of a more pragmatic and practical standpoint, given the need for a 'best estimate' under tight time constraints and in the absence of perfect data. This consideration is starting to be recognised within academia: "models need to take into account the wider business context; disregard for this context is one of the reasons why there has been relatively limited success in the transfer of academic modeling technology into the real world" (Birkin et al., 2010, page 442). Consequently there must be a balance in the location planning team between technical capability and an ability to engage in broader business strategy - in doing so increasing cultural proximity with the senior managers who would appraise the validity of the research produced. As one manager suggested:

"I need analysts who technically are very good, but are... not getting too hung up on being very purist" (Commercial Information Manager, Electrical Retailer).

For some analysts the legitimisation process involved convincing stakeholders of the degree of in-depth analysis involved in location planning by explaining the basic analytical procedures underpinning the strategic advice:

"they need to fundamentally understand how you arrived at an answer.... you don't necessarily show people the model itself, you don't necessarily show them an algorithm, but... enough for people to know that there is some science involved" (Site Research Consultant, Non-Food Retailer).

By contrast, some departments were wary of revealing too much of their methods and techniques due to the possible risks to legitimacy that could arise from such knowledge being used by different interest groups to challenge the location team over the longer term. 
Across the technically advanced and legitimised location planning departments there was a strong consensus that, while in-depth analysis should be conducted to qualify strategic advice relating to portfolio development, its appropriate distillation into written and verbal presentation at Board level was critical to achieving engagement. This was complicated by the natural tendency of location specialists to be focused on analytics rather than persuasive presentation. Related to this, there was a continued need to "sense-check" modelled outputs since glaring errors would risk losing previously earned legitimacy:

“... that's very dangerous for a location planning team, because those outputs will be used, if they're not making any commonsense, to...potentially marginalise the department by others that have got a vested interest to do so within the organisation" (Head of Site Location Services, Location Planning Consultancy).

The importance of being able to "sell" location planning expertise was most acute amongst location planning consultancies quickly having to establish a degree of currency with senior decision-makers within the client organisation, despite management's likely low level of knowledge in the area. Interviews with location planning consultants confirmed that this may lead them to select slightly sub-optimal models due to their intuitive explanatory capabilities:

"there are certainly occasions where we will step back from what is the statistically strongest model to one which we know we will be able to explain and achieve agreement with the retailer that we're working with" (Director, Location Planning Consultancy).

While the outward facing presentation of the location planning department was widely recognised as a critical factor in gaining legitimacy for the function, this does not imply neglecting the continued provision of accurate and timely strategic advice. To this end, all of the departments that we regarded as proactive focused a great deal on model development and the retrospective analysis of forecasting accuracy in order to generate transferable learning.

\section{Maintaining an independent, analytical perspective}

Establishing a distinct location planning department within the retailer's organisational structure was widely perceived as important in contributing to intra-firm legitimacy by providing a clear separation from competing special interests. This was a concern most acutely felt within less well-developed location functions, which were often linked to 
Property Departments, where analysts at times felt pressured to reach particular conclusions. By contrast, proactive departments repeatedly emphasised the importance of maintaining focus on independent strategic advice informed by data and experience rather than by any third party influences. It was explicitly acknowledged that while advice would not always be accepted by senior management, the dispassionate assessment of data was regarded as the long term bedrock of building credibility:

"you've got to actually stand up for [your data analysis]...if you're going to be overruled, that's fine. They have rank, they can overrule you, but you can't move your position away from what the facts objectively tell you... and usually you're respected" (Head of Site Location Services, Location Planning Consultancy).

The lengthy building of a reputation for integrity and reliability also relies on consistent methodologies and a format of written and verbal presentation with which the senior decision-makers can become familiar and, ultimately, in which they can invest their own intellectual capital. As a result, changes to accepted "truths" must be handled sensitively, with an awareness of the effects on the perceptions of senior management:

"[The Board are happy for] a Site Research Manager challenging the current norm, but I think, in terms of the way things are presented to them, they don't want any surprises. They don't want one week to be presented with a forecast that's based on one methodology... and then the next week, they don't get the same inputs, they don't get given the same information" (Senior Analyst, Food Retailer).

\section{Conclusion}

Economic geography research has consistently emphasised the role of retail location network planning supported by accurate forecasting methodologies (Birkin et al., 2002; Wrigley, 1988). The location analysis function is therefore central to exploiting the opportunities inherent in the current store portfolio and exploring new store developments over the longer term (cf. March, 1991). This paper has employed a qualitative methodology with analysts and managers in retail location planning departments to explain the conundrum that while economic geography has contributed to the development of a wide range of analytical techniques to inform network planning, the degree to which these are invested in and employed within practical retail decisionmaking is highly variable. We have developed a three-fold typology of retailers' approaches to store network decision-making that differ in: the degrees of sophistication applied to portfolio analysis; the resource that is dedicated to network planning and site 
assessment; and also the credence that an independent analytical view is afforded by senior management. By understanding location decision-making as embedded within intra-firm relational social networks that are in turn underpinned by unequal power relations, we have sought to better conceptualise the differences in approach between retailers. Specifically, by drawing on theories from strategic management we have identified rigidities that may become embedded within operating structures and social relations which can hinder necessary strategic adaptation. As such, the persistence of lock-in to established belief systems can reinforce a persistent lack of legitimacy within the firm in relation to the provision of informed and analytical strategic advice.

Overcoming both routine and resource rigidity is critical if retailers are fully to realise the benefits that analytical techniques and analysis can offer. Interrogating the successful negotiation of these factors within the fully developed proactive departments we identify has offered some perspectives on how to achieve legitimacy and a role in 'interactive strategizing' (cf. Jarzabkowski, 2005):

First, it is evident that the ability of management to interpret the core message of the information provided will, in part, determine whether location planning investment will be forthcoming and also whether senior management can 'digest' it. It is well-known that apparent 'scientific rigour' attributed to quantitative financial models and metrics are often used to legitimise behaviour (Hall, 2006), but information must be in a format that lends itself to rapid and credible comprehension by management. It is known more widely that failure to act may come from 'the presence of complex systems or technologies that are inherently difficult to understand' (Cannon and Edmondson, 2005, page 301-2). A focus must be maintained on appropriate strategic presentation at board level - location planning departments must select the right representatives for such interaction, not necessarily the best analysts. Losing such physical proximity with senior decision-makers can seriously affect the department's influence within a retailer's decision-making network.

Second, given that power stemming from proximity to influential stakeholders within intra-firm relational geometries is uneven (Jones and Search, 2009; Yeung, 2005a; 2005 b), it is important that the location planning function must not be seen as a silo within the retail organisation but as a source of wider strategic advice and data beyond 
store forecasting (cf. Aaker, 2008). Indeed, as Bathelt and Glückler (2005, page 1557) warn:

'the generation and use of resources systematically depend on the structure of the social relations and institutional conditions which affect the course of economic transactions, the framework for interpretations, and the choice of strategies'.

By challenging any silo structure and mentality, the function places itself as a potential leader in retail expansion planning rather than as an adjunct to a property department. This recasting of the role of a location planning team improves organisational proximity with other parts of the business but is clearly challenging as it involves the renegotiation of culture(s) of work which is itself a gradual and politicised process (cf. Faulconbridge, 2008).

Third, a focus on consistent performance over an extended period of time is a prerequisite for legitimisation. At the level of the location planning department, a relentless focus on forecast accuracy, the continued refinement of assessment techniques, as well as the development of highly focused strategic communications are critical. Only in bringing these factors together can the outward-facing professionalization of the function and, in turn, legitimacy become established. In particular, interactions with senior decision-makers must become 'consistent and predictable, not only meeting constituent needs, but also eliminating uncertainties and fostering a sense of constituent control' (Suchman, 1995, page 596).

Finally we argue that understanding the organisational, political and broader relational context of retail firms is essential if we are to fully comprehend the decision-making process that underpins the dynamic nature of contemporary retail geographies. Through our close dialogue with location planning analysts we have sought a better conceptualisation of these relational networks. We have also elaborated upon the constituent power relations between corporate actors, which lead to more complex outcomes than catchment modelling and analysis (one of the traditional staples of economic geography) may initially have us believe were to be found. Models are one thing: their intelligent application and consideration within the firm may be something quite different. 
Table 1: Principal site evaluation tools and techniques

\begin{tabular}{|c|c|c|}
\hline Technique & Details & $\begin{array}{l}\text { Indicative research } \\
\text { literature }\end{array}$ \\
\hline Experience/Experimental & $\begin{array}{l}\text { "Rule of thumb" procedures } \\
\text { often employed "on site" where } \\
\text { the benefits of experience, } \\
\text { observation and intuition drive } \\
\text { decision-making. }\end{array}$ & $\begin{array}{l}\text { Wood and Tasker } \\
(2008)\end{array}$ \\
\hline Checklist & $\begin{array}{l}\text { Procedure to systematically } \\
\text { evaluate the value of (and } \\
\text { between) site(s) on the basis of a } \\
\text { number of established variables. }\end{array}$ & $\begin{array}{l}\text { Lilien and Kotler } \\
\text { (1983) }\end{array}$ \\
\hline Ratio & $\begin{array}{l}\text { Assumes that if a retailer has a } \\
\text { given share of competing } \\
\text { floorspace in an area, then it will } \\
\text { achieve that same proportion of } \\
\text { total sales available. }\end{array}$ & Rogers (1992) \\
\hline Analogues & $\begin{array}{l}\text { Existing store (or stores) similar } \\
\text { to the site are compared to it to } \\
\text { tailor turnover expectations }\end{array}$ & Clarke et al. (2003) \\
\hline Cluster & $\begin{array}{l}\text { Analysis of clusters in analogue } \\
\text { store data to form groups and } \\
\text { permit segmentation }\end{array}$ & $\begin{array}{l}\text { Schaffer and Green } \\
\text { (1998) }\end{array}$ \\
\hline Discriminant analysis & $\begin{array}{l}\text { A screening tool or decision aid } \\
\text { for low value investments. Uses } \\
\text { existing store performance to } \\
\text { identify those variables that best } \\
\text { explain the differences between } \\
\text { pre-selected groups of stores. } \\
\text { Site is then allocated to relevant } \\
\text { turnover group. }\end{array}$ & $\begin{array}{l}\text { Mendes and Themido } \\
(2004)\end{array}$ \\
\hline Multiple Regression & $\begin{array}{l}\text { Attempts to define a correlation } \\
\text { between store sales and variables } \\
\text { within the catchment that } \\
\text { influence performance }\end{array}$ & Morphet (1991) \\
\hline $\begin{array}{l}\text { Geographical Information } \\
\text { Systems (GIS) }\end{array}$ & $\begin{array}{l}\text { Spatial representation of geo- } \\
\text { demographic and retail data that } \\
\text { is based on digitalized } \\
\text { cartography and draws on } \\
\text { relational databases' }\end{array}$ & Hernández (2007) \\
\hline $\begin{array}{l}\text { Spatial } \\
\text { Interaction/Gravity/Entropy- } \\
\text { Maximizing Modelling }\end{array}$ & $\begin{array}{l}\text { Derived from Newtonian laws of } \\
\text { physics based on the relationship } \\
\text { between store attractiveness and } \\
\text { distance from consumers. May } \\
\text { operate "within" a GIS }\end{array}$ & Birkin et al. (2010) \\
\hline Neural Networks & $\begin{array}{l}\text { Computer based models } \\
\text { explicitly represent the neural } \\
\text { and synaptic activity of the } \\
\text { biological brain. }\end{array}$ & Birkin et al. (2002) \\
\hline
\end{tabular}


Table 2: Different retailer approaches to portfolio decision-making

\begin{tabular}{|c|c|c|c|c|c|}
\hline Location planning expertise & $\begin{array}{l}\text { Degree of } \\
\text { sophistication }\end{array}$ & Influence & $\begin{array}{l}\text { Retailer } \\
\text { size }\end{array}$ & Representation in decision-making & Use of sales forecast \\
\hline $\begin{array}{l}\text { "Administrative" } \\
\text { Little appreciation for } \\
\text { location planning within } \\
\text { retailer. Low legitimization }\end{array}$ & \begin{tabular}{l|} 
Low. \\
Unlikely to be a \\
stand-alone location \\
planning department. \\
Forecasts likely \\
produced by Property \\
Department for \\
means of investment \\
appraisal. Possibly a \\
GIS analyst. \\
\end{tabular} & $\begin{array}{l}\text { Internally orientated } \\
\text { to department (- } \\
\text { likely Property). }\end{array}$ & $\begin{array}{l}\text { Typically } \\
\text { small }\end{array}$ & $\begin{array}{l}\text { Lack of representation at Store } \\
\text { Development Sub-Board } \\
\text { Procedural strategizing } \\
\text { Likely store development strategy } \\
\text { and forecasts set by Property } \\
\text { Department. High influence of } \\
\text { senior management on store } \\
\text { development over and above } \\
\text { catchment data analysis. }\end{array}$ & $\begin{array}{l}\text { Sales forecast not } \\
\text { necessarily produced by } \\
\text { location planning (ie. } \\
\text { independent) department }\end{array}$ \\
\hline $\begin{array}{l}\text { "Responsive" } \\
\text { Some recognition of value of } \\
\text { location planning knowledge } \\
\text { within retailer. } \\
\text { Conducts sales forecasts for } \\
\text { investment appraisals of new } \\
\text { developments as required. } \\
\text { May also develop ideal store } \\
\text { strategy. }\end{array}$ & $\begin{array}{l}\text { Medium } \\
\text { Use of a range of } \\
\text { techniques but likely } \\
\text { ongoing relationship } \\
\text { with consultancy for } \\
\text { expertise. Small team. }\end{array}$ & $\begin{array}{l}\text { Partial boundary } \\
\text { spanning. } \\
\text { Catchment and } \\
\text { customer data not } \\
\text { effectively used across } \\
\text { organisation }\end{array}$ & Various & $\begin{array}{l}\text { Possible personal representation } \\
\text { by Location Planning Department } \\
\text { Manager but more likely (edited?) } \\
\text { location planning report } \\
\text { distributed at meeting } \\
\text { Various strategizing } \\
\text { characteristics across cases } \\
\text { (elements of both Interactive and } \\
\text { Procedural strategizing) } \\
\text { Potential for Property Department } \\
\text { influence over and above Location } \\
\text { Planning Department. }\end{array}$ & $\begin{array}{l}\text { Sales forecast produced and } \\
\text { commonly considered in } \\
\text { investment appraisal at } \\
\text { Store Development Board } \\
\text { Some exceptions where } \\
\text { disagreements with Property } \\
\text { Department arise. }\end{array}$ \\
\hline $\begin{array}{l}\text { "Proactive" } \\
\text { Highly valued and legitimized } \\
\text { within retailer. } \\
\text { Drives forward its own } \\
\text { research \& insights on store } \\
\text { performance, catchments and } \\
\text { ideal strategy for portfolio } \\
\text { development. }\end{array}$ & $\begin{array}{l}\text { High } \\
\text { Range of techniques } \\
\text { with internal } \\
\text { expertise in model } \\
\text { development. Large } \\
\text { team }\end{array}$ & $\begin{array}{l}\text { Boundary spanning } \\
\text { Influence and data } \\
\text { feeds into Marketing, } \\
\text { Finance, Operations, } \\
\text { Store Space Planning, } \\
\text { Trading }\end{array}$ & Large & $\begin{array}{l}\text { Representation by Location } \\
\text { Planning Department at Store } \\
\text { Development Board } \\
\text { Interactive strategizing }\end{array}$ & $\begin{array}{l}\text { Sales forecast automatically } \\
\text { feeds into investment } \\
\text { appraisal for consideration } \\
\text { at Store Development } \\
\text { Board }\end{array}$ \\
\hline
\end{tabular}


Table 3: Core rigidities identified within retailers in introducing increased location planning sophistication

\begin{tabular}{|c|c|c|}
\hline $\begin{array}{l}\text { Type of } \\
\text { rigidity }\end{array}$ & $\begin{array}{l}\text { Core rigidity relating } \\
\text { to location planning }\end{array}$ & Examples of comments from interviews \\
\hline Resource & $\begin{array}{l}\text { Lack of expertise and } \\
\text { intellectual investment }\end{array}$ & $\begin{array}{l}\text { "I am a 'one man band', so all knowledge \& experience resides with one person." (Customer Information Manager, Non- } \\
\text { Food Retailer). } \\
\text { "it is really hard, because, especially sitting in the Property Department, you've got like so many people saving money on rent } \\
\text { and rates and energy bills... and you just think, you know, Site Research is me, I'm really, really busy, but I'm } \\
\text { just...there... because you're not seen to be... saving money or making money" (Site Research Analyst, Non-Food Retailer). }\end{array}$ \\
\hline Resource & $\begin{array}{l}\text { Lack of physical } \\
\text { resource and } \\
\text { infrastructure } \\
\text { investment }\end{array}$ & $\begin{array}{l}\text { "the budgets are very tight... I think that comes down from the fact that ... the business doesn't necessarily understand fully the } \\
\text { benefit of Location Planning. It's not... a case of saying... Location Planning equals x million pounds on the... bottom line" } \\
\text { (Location Planning Manager, Non-Food Retailer). } \\
\text { "you can understand that the priority to the business changes, and therefore... the importance of having a dedicated resource, } \\
\text { for a company of our size, probably isn't... the priority... and therefore you're reliant on ... trying to pull from other resource } \\
\text { within the business" (Property Director, Non-Food Retailer). }\end{array}$ \\
\hline Routine & $\begin{array}{l}\text { Lack of commitment } \\
\text { by senior management }\end{array}$ & $\begin{array}{l}\text { "When you effectively don't have buy-in from the company at a senior level... [effectively] you're saying it's not that } \\
\text { important to the business for us to bother taking an interest in whether we should... take Store Xor Store Y" (Site Research } \\
\text { Analyst, Food Retailer). } \\
\text { "the Department's fairly new, so we're trying to change things so that we get more input certainly in the meeting itself and we } \\
\text { can try and present, like a lot of the other retailers do, you know, present the site... what's the catchment like, etc., but } \\
\text { currently, we just send it off in a report and we don't hear anything" (Site Research Manager, Food Retailer). }\end{array}$ \\
\hline Routine & $\begin{array}{l}\text { Lack of } \\
\text { comprehension by } \\
\text { senior management }\end{array}$ & $\begin{array}{l}\text { "They're not convinced of the need for us to go out on site. They think that should be their job and that we sit in the office and } \\
\text { do the numbers, and give them maps." (Location Planning Manager, Food Retailer). } \\
\text { "I don't know if it's a typical Property mindset, but they've already got their own answer anyway. They know what they want, } \\
\text { and if they're trying to push a site forward, they're going to" (Site Research Analyst, Non-Food Retailer). } \\
\text { "it used to be a case of key directors - Chairman, Property Director, Retail Director - going round in a car ...they would } \\
\text { effectively decide there and then, at the site, whether they wanted to do it, and they'd agree a sales number, which would then } \\
\text { obviously be appraised, put into a financial appraisal, but how robust, you know, and what the returns were, who knows? " } \\
\text { (Site Research Manager, Food Retailer). }\end{array}$ \\
\hline Routine & $\begin{array}{l}\text { Engrained } \\
\text { organisational and } \\
\text { reporting structures }\end{array}$ & $\begin{array}{l}\text { "[Our head of team is] trying to get them to agree to let him be present at the [decision-making] meeting, because currently } \\
\text { he's not, and we don't get a copy of the minutes, so we don't know whether it's been approved, whether they agreed our sales } \\
\text { number, or whether they approved it on their own number. We don't know whether our reports get edited" (Location } \\
\text { Planning Manager, Food retailer). }\end{array}$ \\
\hline
\end{tabular}




\section{References}

Aaker D A, 2008, Spanning Silos: The New CMO Imperative (Harvard Business School Publishing, Boston, MA)

Allen J. 2003 Lost Geographies of Power (Blackwell, Oxford)

Amin A, Cohendet P, 2004, Architectures of Knowledge. Firms, Capabilities, and Communities. Oxford, UK: Oxford University Press.

Armstrong M, De S, Densham P J, Lolonis P, Rushton G, Tewari V 1990, “A knowledgebased approach for supporting locational decision-making" Environment and Planning B-Planning \& Design 17 341-64

Arthur W 1989, “Competing technologies, increasing returns, and lock-in by historical events" Economic Journal 99 116-31

Bathelt H, Glückler, J 2003, “Toward a relational economic geography” Journal of Economic Geography, 3 117-144

Bathelt H, Glückler J, 2005, "Resources in economic geography: from substantive concepts towards a relational perspective" Environment and Planning A 37 1545-1563

Beaverstock J, Faulconbridge J and Hall S 2010, "Professionalization, legitimization and the creation of executive search markets in Europe" Journal of Economic Geography 10 $825-843$

Bennison D, Clarke I and Pal J 1995, "Locational decision making in retailing: an exploratory framework for analysis" International Review of Retail, Distribution \& Consumer Research 5 1-20

Birkin M, Clarke G, Clarke M 2002, Retail Geography \& Intelligent Network Planning (John Wiley \& Sons, Chichester)

Birkin M, Clarke G, Clarke M 2010, "Refining and operationalizing entropy-maximizing models for business applications" Geographical Analysis 42 422-445

Bryman A, Bell E, 2003, Business Research Methods (Oxford University Press, Oxford)

Cannon M, Edmondson, A 2005, "Failing to learn and learning to fail intelligently: how great organizations put failure to work to innovate and improve" Long Range Planning 38 299-319

Clark G 1998, "Stylized facts and close dialogue: methodology in economic geography" Annals of Association of American Geographers 88 73-87 
Clark G, 2010, "Human nature, the environment, and behaviour: explaining the scope and geographical scale of financial decision-making" Geografiska Annaler: Series B, Human Geography 92 159-173

Clarke I, Mackaness, W 2001, "Management 'intuition': an interpretative account of structure and content of decision schemas using cognitive maps" Journal of Management Studies 38 147-72

Clarke I, Mackaness W, Ball B, Horita M 2003, "The devil is in the detail: visualising analogical thought in retail location decisionmaking" Environment and Planning BPlanning \& Design 30 15-36

Coe N, Hess M 2005, “The internationalization of retailing: implications for supply network restructuring in East Asia and Eastern Europe" Journal of Economic Geography 5 449-73

Coe N and Lee Y-S 2006, "The strategic localization of transnational retailers: the case of Samsung-Tesco in South Korea" Economic Geography 82 61-88

Coe N, Wrigley N 2007, "Host economy impacts of transnational retail: the research agenda" Journal of Economic Geography 7 341-71

Currah A,Wrigley N, 2004, "Networks of organizational learning and adaptation in retail TNCs" Global Networks: A Journal of Transnational Affairs 4 1-23

Daft R, Weick K 1984, "Toward a model of organizations as interpretation systems" Academy of Management Review 9 284-95

Dicken P, Malmberg A 2001, "Firms in territories: a relational perspective" Economic Geography 77 345-363

Dicken P, Thrift N 1992 "The organisation of production and the production of organisation: why enterprises matter in the study of geographical industrialisation" Transactions, Institute of British Geographers NS 17 279-91

Durand C, Wrigley N 2009, "Institutional and economic determinants of transnational retailer expansion and performance: a comparative analysis of Wal-Mart and Carrefour" Environment and Planning A 41 1534-55

Faulconbridge J 2006, "Stretching tacit knowledge beyond a local fix? Global spaces of learning in advertising professional service firms" Journal of Economic Geography 6 $517-540$

Faulconbridge J 2007, "Relational networks of knowledge production in transnational law firms" Geoforum 38 925-940 
Faulconbridge, J 2008, "Negotiating cultures of work in transnational law firms" Journal of Economic Geography 8 497-517

Faulconbridge J 2010a, "TNCs as embedded social communities: transdisciplinary perspectives" Critical Perspectives on International Business 6 273-290

Faulconbridge J 2010b, “Global architects: learning and innovation through communities and constellations of practice" Environment and Planning A 422842 - 2858

Faulconbridge J, Hall, S 2009 "Organisational geographies of power: introduction to special issue" Geoforum 40 785-789

Gibson C, Birkinshaw J 2004, "The antecedents, consequences, and mediating role of organizational ambidexterity" Academy of Management Journal 47 209-226

Gilbert C 2005, "Unbundling the structure of inertia: resource versus routine rigidity" Academy of Management Journal 48 741- 763

Goodrick E, Reay T 2010, "Florence Nightingale endures: legitimizing a new professional role identity" Journal of Management Studies 47 55-84

Grabher G 1993, "The weakness of strong ties; the lock-in of regional development in the Ruhr area" in Grabher, G ed The Embedded Firm: On the Socioeconomics of Industrial Networks (Routledge, London), pp 255-77

Hall, S 2006, "What counts? Exploring the production of quantitative financial narratives in London's corporate finance industry" Journal of Economic Geography 6 661-678

Hassink R 2007, “The strength of weak lock-ins: the renewal of the Westmunsterland textile industry" Environment and Planning A 39 1147-65

Henderson J, Dicken, P, Hess, M, Coe, N, Yeung, H 2002, “Global production networks and the analysis of economic development" Review of International Political Economy, 9 436-464

Hendry K, Kiel G, Nicholson G 2010, "How boards strategise: a strategy as practice view" Long Range Planning 43 33-56

Hernández T 2007, "Enhancing retail location decision support: The development and application of geovisualization" Journal of Retailing \& Consumer Services 14 249-58

Hernández T, Bennison D 2000, "The art and science of retail location decisions" International Journal of Retail \& Distribution Management 28 357-67

Hernández T, Bennison D, Cornelius S 1998, "The organisational context of retail locational planning" GeoJournal 45 299-308

Hess M, 2004, "'Spatial' relationships? Towards a reconceptualization of embeddedness" Progress in Human Geography 28 165-186 
Hess M, Yeung H, 2006, ”Whither global production networks in economic geography? Past, present, and future“ Environment and Planning A 38 1193-1204

Hoon C 2007, "Committees as strategic practice: the role of strategic conversation in a public administration" Human Relations 60 921-52

Hughes R, Hallsworth A, Clarke G 2009, "Testing the effectiveness of the proposed UK 'competition test'" The Service Industries Journal 29 569-590

Jarzabkowski P 2005, Strategy as Practice: An Activity Based Approach (Sage, London)

Jones A, Search P 2009, "Proximity and power within investment relationships: the case of the UK private equity industry" Geoforum 40 809-819

Kohsaka H 1993, "A monitoring and locational decision support system for retail activity" Environment and Planning A 25 197-211

Lam A 2000, "Tacit knowledge, organizational learning and societal institutions: an integrated framework" Organization Studies 21 487-513

Lave J, Wenger E, 1991, Situated Learning. Legitimate Peripheral Participation (Cambridge University Press, Cambridge)

Leonard-Barton D 1992, "Core capabilities and core rigidities: a paradox in managing new product development" Strategic Management Journal 13 111-25

Leyshon A, Thrift N, 1997 Money/Space, Geographies of Monetary Transformation (Routledge,London)

Lilien G, Kotler P 1983, Marketing Decision Making - A Model Building Approach (Harper \& Row Publishers, New York)

Lowe M, Wrigley N 2010, “The 'continuously morphing' retail TNC during market entry: interpreting Tesco's expansion into the USA" Economic Geography 86 381-408

March J 1991, "Exploration and exploitation in organizational learning” Organization Science 2 71-87

Marshall J, Willis R, Coombes M, Raybould S Richardson R 2000, "Mutuality, demutualization and communities: The implications of branch network rationalization in the British building society industry" Transactions of the Institute of British Geographers 25 355-377

Mendes A, Themido I H 2004, "Multi-outlet retail site location assessment" International Transactions in Operational Research 11 1-18

Miller E, Lerman S 1981, "Disaggregate modelling and decisions of retail firms: a case study of clothing retailers" Environment and Planning A 13 729-46 
Moodysson J 2008, "Principles and practices of knowledge creation: on the organization of "buzz" and "pipelines" in life science communities" Economic Geography 84 449-69

Morphet C 1991, “Applying multiple regression analysis to the forecasting of grocery store sales: an application and critical appraisal" International Review of Retail, Distribution \& Consumer Research $1329-351$

Nelson R, Winter S 1982, An Evolutionary Theory of Economic Change (Harvard University Press, Cambridge, MA)

Pal J, Medway D, Warnaby G 2010, "When the tide goes out: gender, leadership and failure in the retail sector" Environment and Planning A 421769 - 1774

Penny N, Broom D 1988, "The Tesco approach to store location" in Wrigley, N ed Store Choice, Store Location and Market Analysis (Routledge, London), pp 106-19

Pioch E, Byrom J 2004, "Small independent retail firms and locational decision-making: outdoor leisure retailing by the crags" Journal of Small Business and Enterprise Development $11222-32$

Poole R, Clarke G, Clarke D 2006, "Competition and saturation in West European grocery retailing” Environment and Planning A 38 2129-56

Raisch S, Birkinshaw J 2008, “Organizational ambidexterity: antecedents, outcomes, and moderators" Journal of Management 34 375-409

Reay T, Golden-Biddle K, Germann K 2006, "Legitimizing a new role: small wins and microprocesses of change" Academy of Management Journal 49 977-98

Reay T, Hinings C 2009, "Managing the rivalry of competing institutional logics" Organization Studies 30 629-52

Reus T, Ranft A, Lamont B, Adams G 2009, “An interpretive systems view of knowledge investments" Academy of Management Review 34382

ReVelle C, Eiselt H 2005, "Location analysis: A synthesis and survey" European Journal of Operational Research 165 1-19

Reynolds J, Wood S 2010, "Location decision-making in retail firms: evolution and challenge" International Journal of Retail \& Distribution Management 38 828-845.

Rogers D 1992, Retail Location Analysis in Practice (Oxford Institute of Retail Management, Longman, Oxford)

Rogers D 2005, "Developing a location research methodology" Journal of Targeting, Measurement \& Analysis for Marketing 13 201-8

Schaffer C, Green P 1998, “Cluster-based market segmentation: some further comparisons of alternative approaches" Journal of the Market Research Society 40 155-63 
Schoenberger E 1994, "Corporate strategy and corporate strategists: power, identity, and knowledge within the firm" Environment and Planning A 26 435-51

Schoenberger E 1997, The Cultural Crisis of the Firm (Blackwell, Oxford)

Simon H 1957, Administrative Behavior 4th Edition (Macmillan, New York)

Sornn-Friese H, Simoni Sorensen J 2005, "Linkage lock-in and regional economic development: the case of the Øresund medi-tech plastics industry" Entrepreneurship \& Regional Development 17 267-91

Strauss K 2008, "Re-engaging with rationality in economic geography: behavioural approaches and the importance of context in decision-making" Journal of Economic Geography: 8 137-156

Strauss K 2009, "Cognition, context, and multimethod approaches to economic decision making" Environment and Planning A 41 302-17

Suchman, M C 1995, "Managing legitimacy: strategic and institutional approaches", Academy of Management Review 20:571-610

Tacconelli W, Wrigley N 2009, “Organizational challenges and strategic responses of retail TNCs in post-WTO-entry China” Economic Geography 85 49-73

Theodoridis C, Bennison D 2009, "Complexity theory and retail location strategy" International Review of Retail, Distribution \& Consumer Research 19 389-403

Tollin K, Jones R 2009, “Marketing logics for competitive advantage?” European Journal of Marketing $\mathbf{4 3}$ 523-50

Uzzi B 1997, "Social structure and competition in interfirm networks: the paradox of embeddedness" Administrative Science Quarterly 42 35-67

Volberda H 2006, "Strategic flexibility creating dynamic capability” in Faulkner, D O and Campbell, A eds The Oxford Handbook of Strategy (Oxford University Press, Oxford), pp 939-98

Weick K 1979, The Social Psychology of Organizing (Random House, New York)

Weller S 2009, "Shifting spatialities of power: the case of Australasian aviation" Geoforum 40 790-799

Willis R, Marshall J, Richardson R 2001 “The impact of 'branchless banking' on building society branch networks" Environment and Planning A 33 1371-1384

Wood S, Browne S 2007, “Convenience store location planning and forecasting: a practical research agenda" International Journal of Retail \& Distribution Management 35233 55 
Wood S, Lowe M, Wrigley N 2010, “Conceptualising innovative customer-facing responses to planning regulation: the UK food retailers" The Service Industries Journal 30 1967-1990

Wood S, Tasker A 2008, "The importance of context in store forecasting: The site visit in retail location decision-making" Journal of Targeting, Measurement \& Analysis for Marketing 16 139-55

Wrigley N ed 1988, Store Choice, Store Location and Market Analysis (Routledge, Andover, UK)

Wrigley N, Branson J, Murdock A, Clarke G 2009, "Extending the Competition Commission's findings on entry and exit of small stores in British high streets: implications for competition and planning policy" Environment and Planning $A \mathbf{4 1}$ 2063-85

Wrigley N, Coe N, Currah A 2005, "Globalizing retail: conceptualizing the distributionbased transnational corporation TNC" Progress in Human Geography 29 437-57

Yeung H 2003, "Practicing new economic geographies: a methodological examination" Annals of the Association of American Geographers 93 442-462

Yeung H 2005a, "Rethinking relational economic geography" Transactions of the Institute of British Geographers 30 37-51

Yeung H 2005b, "The firm as social networks: an organisational perspective" Growth and Change 36 307-328 